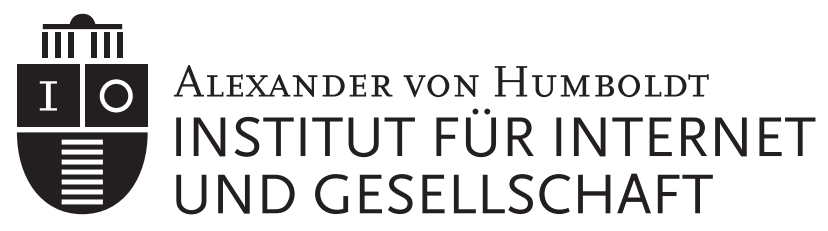
DRAFT PAPER prepared for the 1st Berlin Symposium
on Internet and Society
October 26th to 28th, 2011

\title{
TITLE Innovation, Society and Business: Internet-based Business Models and their Implications
}

\section{Helmut Krcmar}

krcmar@in.tum.de; Chair for Information Systems, Technische Universität München, Boltzmannstr. 3, D-85748 Garching b. München

\section{AUTHOR Markus Böhm}

markus.boehm@in.tum.de; Chair for Information Systems, Technische Universität München, Boltzmannstr. 3, D-85748 Garching b. München

\section{Sascha Friesike}

friesike@internetundgesellschaft.de; Institut für Internet und Gesellschaft, Berlin

\section{Thomas Schildhauer}

schildhauer@ieb.net; Institute of Electronic Business e.V., Affiliate Institute of Berlin University of the Arts, Hardenbergstrasse 9A, D- 
Paper prepared for the 1st Berlin Symposium on Internet and Society, Oct. 25-27, 2011

\title{
Innovation, Society and Business: Internet-based Business Models and their Implications
}

\author{
Helmut Krcmar \\ krcmar@in.tum.de; Chair for Information Systems, Technische Universität München, \\ Boltzmannstr. 3, D-85748 Garching b. München
}

\section{Markus Böhm}

markus.boehm@in.tum.de; Chair for Information Systems, Technische Universität

München, Boltzmannstr. 3, D-85748 Garching b. München

\section{Sascha Friesike}

friesike@internetundgesellschaft.de; Institut für Internet und Gesellschaft, Berlin

\section{Thomas Schildhauer}

schildhauer@ieb.net; Institute of Electronic Business e.V., Affiliate Institute of Berlin University of the Arts, Hardenbergstrasse 9A, D-10623 Berlin, Germany

\begin{abstract}
The term business model became popular with the rise of the Internet and electronic businesses as a means to explain how an organization works. With innovations also the way how customers interact with firms and thus with their products has changed, leading to a world, where companies compete on the basis of their business models. This is also reflected in the many facets of today's business model, ranging from definitions and taxonomies to software supported business model design. This article gives an overview on business model research, discusses trends and suggests a research agenda of particularly interesting domains for future research.
\end{abstract}




\section{Motivation for Business Model Research}

The term business model (BM) became popular with the rise of the Internet and electronic businesses as a means to explain how an organization works. As such it can be traced back to Peter Drucker's question of who is the customer, what does he value and how does an organization intend to earn money (Drucker 1954; Magretta 2002). It is evident that business model research has its roots in strategic management.

Strategic thinking in organizations is typically distinguished along four phases (Gluck 1980; Welge and Al-Laham 2008): The financial planning phase, lasting until the beginning of the 1950ies was characterized by budgeting and project planning in a rather stable and predictable techno-economical development. From the 1950ies on, the external environment became more dynamic and complex. This led to a phase of long-term-planning, where the extrapolation of trends into subsequent years was used as the basis for strategic decisions. Increasing dynamic changes in the external environment, highly volatile economic cycles and a growing speed of technological change required more strategic planning. This strategic planning phase was characterized by the aim to understand an organization's environment and dynamically react with according strategies. Porter's (1980) five forces framework and the generic strategies are good examples. Strategic management eventually extended a sole strategic planning by including the implementation and controlling of strategic decisions.

Drawing on its heritage from strategic management research, the term business model has nowadays also gained popularity among researchers. More than 1.300 scholarly articles can be found by keyword search in the EBSCO Business Source Database between 1947 and 2011. The vast majority of these are 


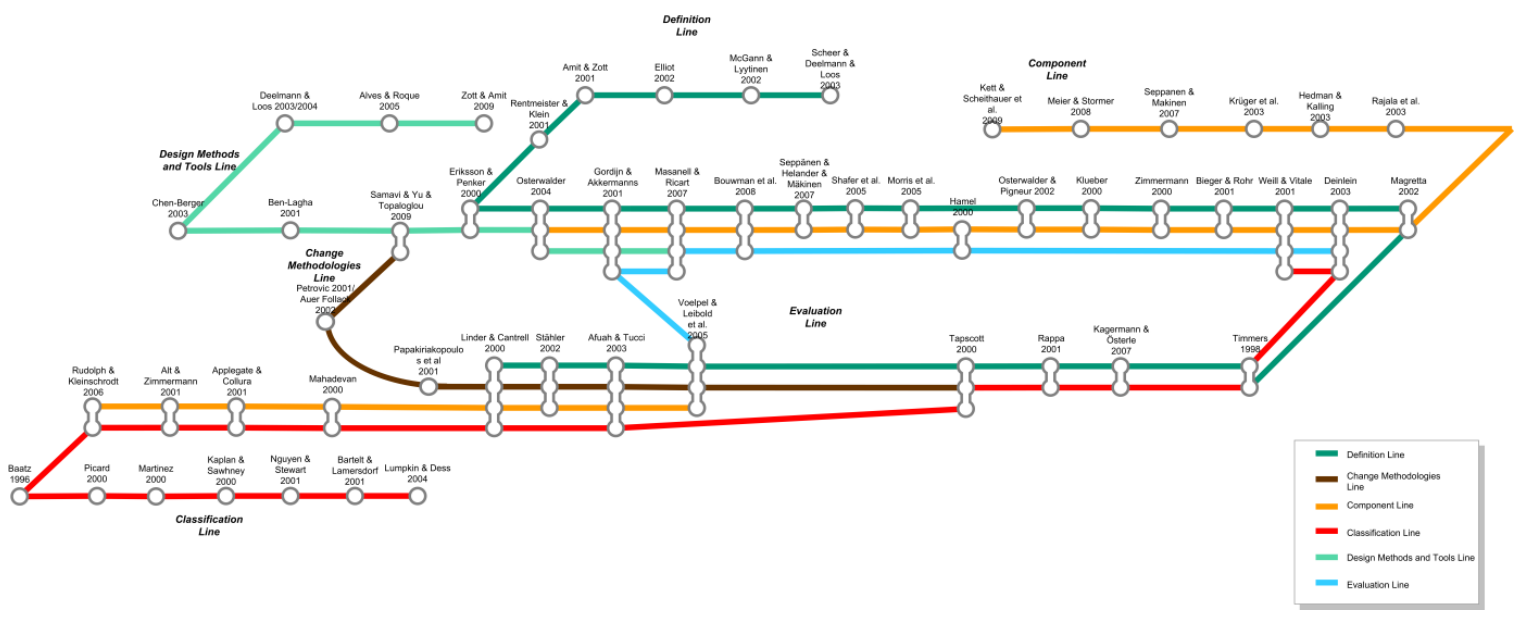

Figure 1: Business Model Research Map

Source: Weiner et al. (2010)

attributed to the past 15 years. Today's business model research shows many facets, ranging from definitions and taxonomies to software supported business model design. Figure 1 provides a non-exhaustive overview on current research in the business model domain. The different lines indicate authors addressing BM definitions (green), components of BM (orange), classifications of BM (red), BM transformation approaches (brown), BM design methods and tools (turquoise), as well as the evaluation of business models (blue).

Innovation in the realm of business models changed the way customers interact with firms and thus with their products. The Internet has drastically changed the idea of the business model and therefore changed its practical implications for both business and society. On the business side we see new ways of revenue generation, new ways of product offerings and new ways of distribution. But the societal changes these new business models bring are as important. Hence, advances in business model research are more important than ever for today's economic and societal development. Major trends, such as business ecosystems, open innovation, freemium services, as well as the need for sustainability highlight the importance of further business model research. This 
article will therefore provide an overview about the state of the art in business model research by summarizing important definitions and by investigating current research streams. It will further discuss the major trends that impact future business model research and identify further research needs within the domain.

In an era in which firms and the value networks they are embedded in compete on basis of their underlying business models in which they provide their products and services, the need for research in this area is obvious. However, what are the topics of most interest and how could they be researched is a topic in need of discussion. This document maps out some possible starting points for that discussion and serves as background for a workshop on business model research in the internet age.

\section{Foundations of Business Models}

Despite the importance of the concept and the large number of scholarly articles, the term business model remains vaguely defined. Until today, no universally accepted definition has been established (Weill et al. 2011). This leads to a large variety of definitions in scholarly and practical literature.

According to Timmers (1998), a "business model is an architecture of the product, service and information flows, including a description of the various business actors and their roles; a description of the potential benefits for the various business actors; a description of the sources of revenues." Rooted in the ebusiness domain, this definition draws on a network view of an organization highlighting product, service and information flows among collaborating actors in order to provide value for a consumer. Thus Timmers is rather explicit about the aspects a business model contains. 
Amit and Zott (2001) focus on the activities required to exploit business opportunities. According to them, "a business model depicts the content, structure, and governance of transactions designed so as to create value through the exploitation of business opportunities."

Magretta (2002) on the other hand takes a more strategic perspective, highlighting an organizations vision. She defines business models as "stories that explain how enterprises work. A good business model answers Peter Drucker's age old questions: Who is the customer? And what does the customer value? It also answers the fundamental questions every manager must ask: How do we make money in this business? What is the underlying economic logic that explains how we can deliver value to customers an appropriate cost?"

Chesbrough and Rosenbloom (2002) try to integrate rather technical perspectives with the strategic perspective. They define the business model as "the heuristic logic that connects technical potential with the realization of economic value."

Similarly, Casadesus-Masanell and Ricart (2010) perceive the business model as "a reflection of the firm's realized strategy". They further define the business model as "the logic of the firm, the way it operates and how it creates value for its stakeholders. Strategy refers to the choice of business model through which the firm will compete in the marketplace. Tactics refers to the residual choices open to a firm by virtue of the business model that it employs" (Casadesus-Masanell and Ricart 2010).

Also Morris et al. (2005) try to integrate different perspectives: strategy, architecture and economics. However they remain rather inexplicit about that and define a business model as a concise representation of how an interrelated set of decision variables in the areas of venture strategy, architecture, and economics are addressed to create sustainable competitive advantage in defined markets." 
Johnson et al. (2008) argue that business models consist of four interlocking elements. Compared to the other definitions, it is new that the authors include resources into their definition. They define a "business model, from our point of view, consists of four interlocking elements that, taken together, create and deliver value." These elements are customer value proposition, profit formula, key resources, and key processes.

Similarly to Timmers who highlights the importance of information, Teece (2010) sees data as one component of a business model. In his understanding a "business model articulates the logic, the data and other evidence that support a value proposition for the customer and a viable structure of revenues and costs for the enterprise delivering that value."

While different definitions of business models differ distinctively, they still share a common ground. Most definitions highlight the value proposition for the customer and the way, how this value is created through the combination of activities. However, the latter part is made more or less explicit across the various definitions. This range of different concepts and interpretations, sub-summarized under the term business model makes it important to be precise about the term. However, as the literature review of Zott et al. (2010) revealed, approximately one-third of the articles did not define the term and took its meaning for granted.

Table 2 provides an overview on various definitions and components of business models as perceived by different authors. 


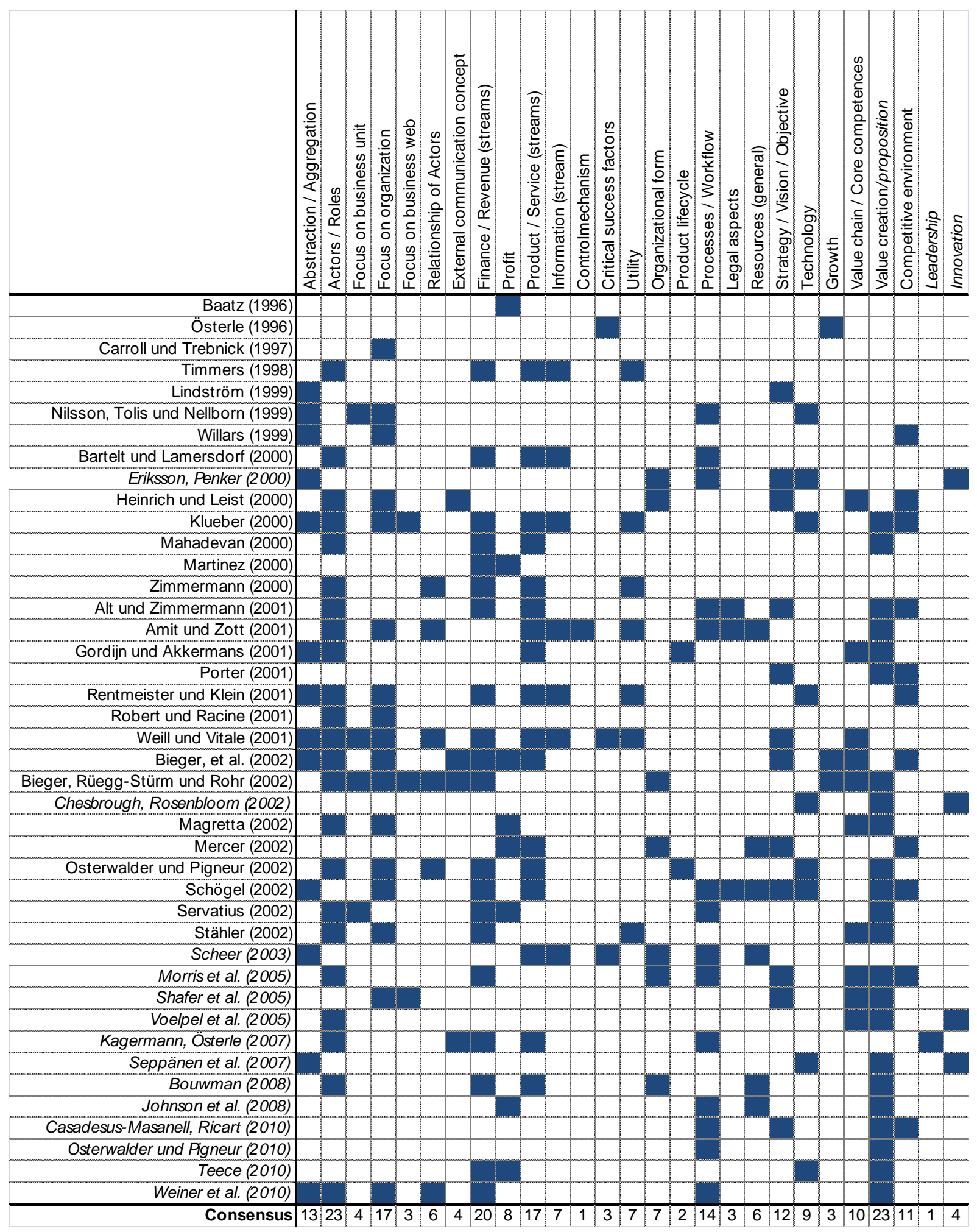

Table 1: Definitions and Components of Business Models

Source: Extension of Scheer et al. (2003); extensions are highlighted in italics 
The variety of definitions also represents the multidisciplinarity of the research domain. Basically three schools of thought can be identified: e-commerce, strategy, and technology \& innovation management (Zott et al. 2010). In ecommerce, business models are used to explain organizational configurations of Internet-based businesses and the firm's role within its ecosystem. Strategy school sees a business model as a model to explain value creation and sources of competitive advantage. Technology \& innovation management strives to understand the commercialization of technology as well as the networked innovation (Zott et al. 2010).

Table 2 shows selected definitions from different schools of thought to exemplify the great variety of the research domain.

\section{Definition}

"The business model is an architecture of the product, service and information flows, including a description of the various business actors and their roles; a description of the potential benefits for the various business actors; a description of the sources of revenues."
School of Thought

E-Commerce

(Timmers 1998)

"A business model describes the rationale of how an organization creates, delivers and captures value"

(Osterwalder and Pigneur 2011)

"Business model, we argue, is a reflection of the firm's realized strategy. [...] Put succinctly, business model refers to the logic of the firm, the way it operates and how it creates value for its stakeholders. Strategy refers to the choice of business model through which the firm will compete in the marketplace."

(Casadesus-Masanell and Ricart 2010)

"The business model is the heuristic logic that connects technical potential with the realization of economic value."

(Chesbrough and Rosenbloom 2002)

Table 2: Approaches to Business Models

Source: Own illustration 


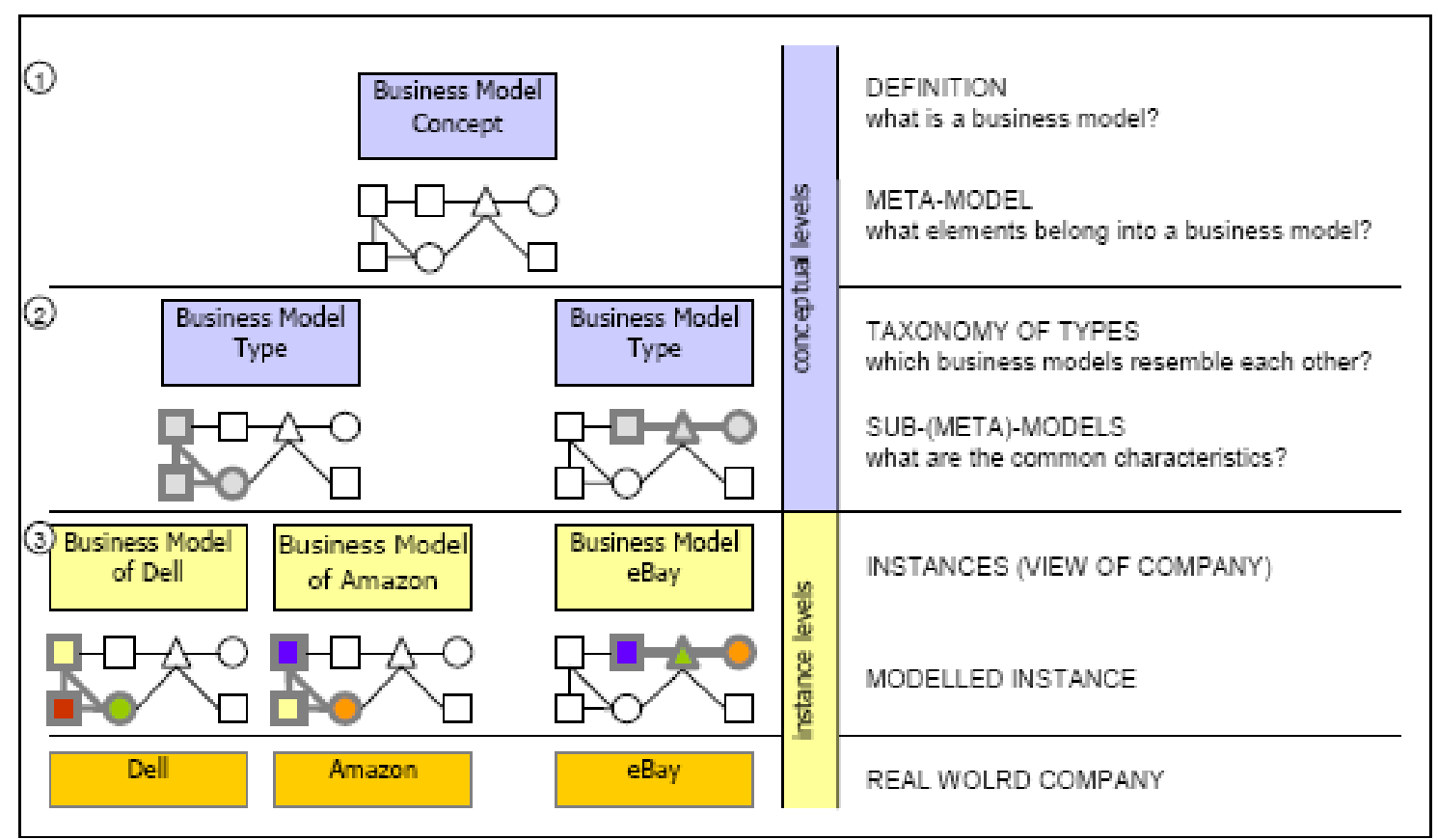

Figure 2: Business Model Concept Hierarchy

Source: Osterwalder et al. (2005)

In literature, the business model concept is addressed at different levels of abstraction, ranging from definitions of the overall concept, to a description of generic types of business models and eventually to the depiction of particular cases. To accommodate for these different levels of abstraction, Osterwalder (2005) has suggested a business model concept hierarchy, represented in Figure 2.

According to Osterwalder et al.'s (2005) concept hierarchy, the business model concept level represents general definitions of business models, abstract concepts that describe what businesses do. It furthermore includes definitions of business model components and meta-models that conceptualize them. The taxonomy level categorizes business models and meta-models by type, sharing common characteristics, such as the industry. Types can be a subclass of an overarching business model concept. The instance level represents concrete real world business models, their conceptualizations, representations and descriptions. 


\section{Business Model Research Streams}

Zott et al. (2010) have conducted a comprehensive literature review on business models. Out of more than 1.200 articles, 103 were found that focus on the business model concept. As described in the 'schools of thought' they can be distinguished in three major research streams.

\section{E-Commerce School}

Out of the plenty of scientific articles, this research stream contributed most to business model research. This can be traced back to the expansion of the Internet and its related technologies that allowed new ways of value creation and distribution (Amit and Zott 2001).

The rapid extension of e-commerce with its large number of business models has lead researchers to classify different e-commerce business models (e.g. Applegate 2001; Tapscott et al. 2000; Timmers 1998; Weill and Vitale 2001). Timmers (1998) for example distinguishes between e-Shops, e-Procurement, eMalls, e-Auctions, Virtual Communities, Collaboration Platforms, Third-Party Marketplaces, Value Chain Integrators, Value Chain Service Providers, Information Brokers, and Trust or other Third parties. Another classification has been introduced by Weill and Vitale (2001), who distinguish between Content Providers, Direct to Customer, Full-Service Provider, Intermediary, Shared Infrastructure, Value Net Integrators, Virtual Communities and Whole of Enterprise/Government.

Another research stream addresses the components of e-business models (Alt and Zimmerman 2001; Applegate 2001; Bonaccorsi et al. 2006; Brousseau and Penard 2006; Mahadevan 2000; Osterwalder 2004). Mahadevan (2000) for instance sees a business model as the aggregation of three streams: value stream, revenue 
stream, and logistical stream. Osterwalder (2004) extends this perception. His framework consists of value proposition, customer segments, partners' network, delivery channel, and revenue stream. These components are integrated through relationship, value configuration, capability, and cost structure.

Drawing on the components of business models, various researchers have developed representations for business models to facilitate development, analysis and communication. Tapscott et al. (2000) have suggested a value map to illustrate value exchanges among participants (partners, customers, suppliers) in a business web. With his business model onthology (BMO), Osterwalder (2004) has suggested a more formalized approach to represent business models. As a result of this, the business model canvas has been developed, a tool to iteratively describe, visualize and analyze business models (Osterwalder and Pigneur 2010). Also Gordijn and Akkermans (Gordijn and Akkermans 2001; Gordijn and Akkermans 2003) have developed a methodology to describe and analyze value exchanges within e-business networks, called e3-value methodology. Leimeister and Krcmar (2004) have proposed a framework to analyze the virtual communities business model. This framework basically consists of a product and service model, an actor model and a revenue model.

Yet another research stream addresses free services offered to customers on the Internet. While this is a popular market entry strategy, firms tend to struggle with the transition to paid services. Clemons (2009) has summarized different business models for monetizing Internet applications. He found that many are based on advertising. However, considering a declining advertising effectiveness, companies should think about other business models. Pauwels and Weiss (2008) have researched the performance implications of the shift from free services to paid services. They especially highlight the role of marketing to accommodate this shift. 


\section{Strategy School}

Among strategy scholars a debate was launched, how business models distinguish from strategy in general and product-market strategy in particular. According to Richardson (2008) a business model bridges strategy formulation and implementation. As such it explains how firm activities work together to execute a strategy. Similarly, Casadesus-Masanell and Ricart (2010) perceive the business model as "a reflection of the firm's realized strategy".

Within the strategy school, one research stream analyzes the performance effects of business models. They basically address the question of what distinguishes successful from unsuccessful business models. Based on a series of 70 interviews with executives and analysts, Lindner and Cantrell (2000) found that successful companies tend to operate effective business models and execute them superiorly. The authors further found that for the case that competition threatens these firms' business models, they relentlessly alter their business model. Giesen et al. (2007) have interviewed more than 700 corporate and public leaders worldwide. They have found that organizations which emphasize business model innovation tend to financially outperform others. Another empirical study in the Biotechnology industry, by Zott and Amit (2008) has found that novelty-centered business models have an effect on firm performance measured as the market value of the firm's equity.

Weill et al. (2011) have conducted a stock market analysis of more than $10^{\prime} 000$ firms, publically traded on U.S. stock exchanges. Therefore they have developed a framework that distinguishes business models along asset types (financial, physical, intangible, human) and asset rights (creator, distributor, landlord, broker). From this framework they have derived 14 different business models such as manufacturer, physical landlord, intellectual property landlord, or contractor. The study found that innovative manufactures, defined as 
organizations that invest more in $\mathrm{R} \& \mathrm{D}$ than industry average, are most valued by the stock market. One example of such an innovative manufacturer would be Apple. Intellectual property landlords, organizations that sell licenses or subscriptions to use their intellectual property rights are also highly valued by the stock market. Disney is one example that has significantly shifted towards this business model and outperformed the S\&P 500 index. Concluding, business models based on innovation and intellectual property appear to be particularly valued by stock markets and thus investors.

Another strategy school research streams deals with the utilization of the business model concept to explain value creation in networks. Especially in domains where value creation typically exceeds firm boundaries, such as in ebusiness, this appears to be an appropriate framework. In their study on value creation in e-business, Amit and Zott (2001) have identified four potential sources of value creation: novelty, lock-in of customers or partners, complementarities in products, service and activities, as well as transaction efficiency.

\section{Innovation and Technology Management School}

Two major research streams can be identified within the innovation and technology management school. One deals with the commercialization of innovative ideas and technologies. The other regards business models as a new dimension of innovation, extending the traditional perception of product, process and organizational innovation (Zott et al. 2010).

Chesbrough and Rosenbloom (2002) have studied the commercialization of Xerox Corporation's first copying machine, initially rejected by other organizations. Its, in those days innovative business model was key to success. The authors complemented this study by analyzing the business models of spin-offs of the company's research center, Xerox PARC. Once again they found, that the 
successful spin-offs tended to have significantly different business models than Xerox. This illustrates the importance of adapted and innovative business models for commercializing new technologies. Comparable findings are reported by Björkdahl (2009), studying the role of business models for creating value from integrating new technologies into a product (technology cross fertilization). Johnson and Suskewicz (2009) have extended the perspective from firm level to the whole industry. In their proposed framework, the business model is one building block for systemic change.

Another research stream focuses on business model innovation and renewal. Giesen et al. (2007) distinguish three types of business model innovation: supply chain innovation, revenue stream innovation, and innovations in value chain positioning. Another form of business model innovation can be seen in open innovation (Chesbrough 2003), where companies try to integrate external ideas or search for another firm to market their developments.

The case of Xerox and its spin-offs (Chesbrough and Rosenbloom 2002) has also highlighted the importance of business model renewal, as many of the new technologies would not have fitted to Xerox's business model. Chesbrough (2010) has analyzed two types of barriers for business model innovation in organizations. One results from the complexity to adjust existing resources and the other from the inability to see the potential of new ideas, being constrained by the current business model. According to different authors, experimentation is key to finding suitable business models (Chesbrough 2010; Hayashi 2009; McGrath 2010). Doz and Kosonen (2010) suggest that incumbent organizations need to develop some sort of agility. To achieve this, strategic sensitivity, leadership unity and resource flexibility are required, as well as the willingness to take risks. In a similar vein, other authors also emphasize the importance of 
behavioral aspects for business model innovations (Santos et al. 2009; Smith et al. 2010).

\section{Trends Affecting Business Model Research}

Different trends can be identified that have an effect on the evolution of business models and thus on future research in this domain. Some of the presumably most influential trends will be presented in the following.

\section{Sustainability}

Cycles of economic up- and downturn are becoming shorter and with it the risk for organizations and economies. Several economic crises are documented in history. Examples are the tulips crisis of 1637 in the Netherlands, the Mississippicrisis of 1720 in France, the first world economic crisis of 1857 or the long depression beginning in 1873. This continued with the great depression (1929), the oil crises (1973 / 1979), the asia crisis (1997) and the dotcom crisis (2000). In recent years we faced the financial crisis (2008) and its extensions leading to the current debt crisis (ARD 2011). People are more and more afraid of that situation and desire a more sustainable economic development, to avoid the threat of high inflation and a significant number of job losses.

In Germany, 425'000 corporations have been founded in the year 2010. This number is opposed by 385'000 liquidations and 168'458 bankruptcies (Institut der Deutschen Wirtschaft Köln 2011), leading to a reduction of the number of organizations in Germany. This large number of liquidations and bankruptcies often imply a loss of capital and jobs, having detrimental economic and societal effects. A famous example of this is the burst of the dot-com bubble in the year 2000, due to a significant number of business failures. 


\section{Ecosystems}

In recent years, many industries have moved away from a strictly sequential production (value chain) to a network of suppliers (value network). A good example of this is the car industry. Beginning with the manually manufacturing unique cars, it has evolved into today's highly modular manufacturing network with several tiers of module suppliers. In the IT industry similar developments can be found, e.g. in e-commerce (Amit and Zott 2001) or cloud computing (Böhm et al. 2009). This evolution towards ecosystems gains momentum through product service systems (PSS). PSS are physical or IT products that are complemented by services. The customer is basically buying a solution for a problem, which is solved by the combination of products and services provided by one or several service providers (Baines et al. 2007).

From a theoretical perspective, this evolution is also manifested in the frameworks applied by researchers and practitioners. With his five forces framework, Porter (1980) has made an important contribution to strategy literature. Here focus is on a single firm's competitive environment, represented by suppliers, customers, potential entrants, substitutes and industry competitors. Over time, the industry has evolved towards multi business organizations. These organizations typically have several business units that individually compete in their markets. Portfolio techniques, such as growth-share matrix of the Boston Consulting Group, have been used as tools to analyze the value and potential of different businesses. This is used to optimize an organization's portfolio of businesses. With the number of businesses being subject to value creation, also the 


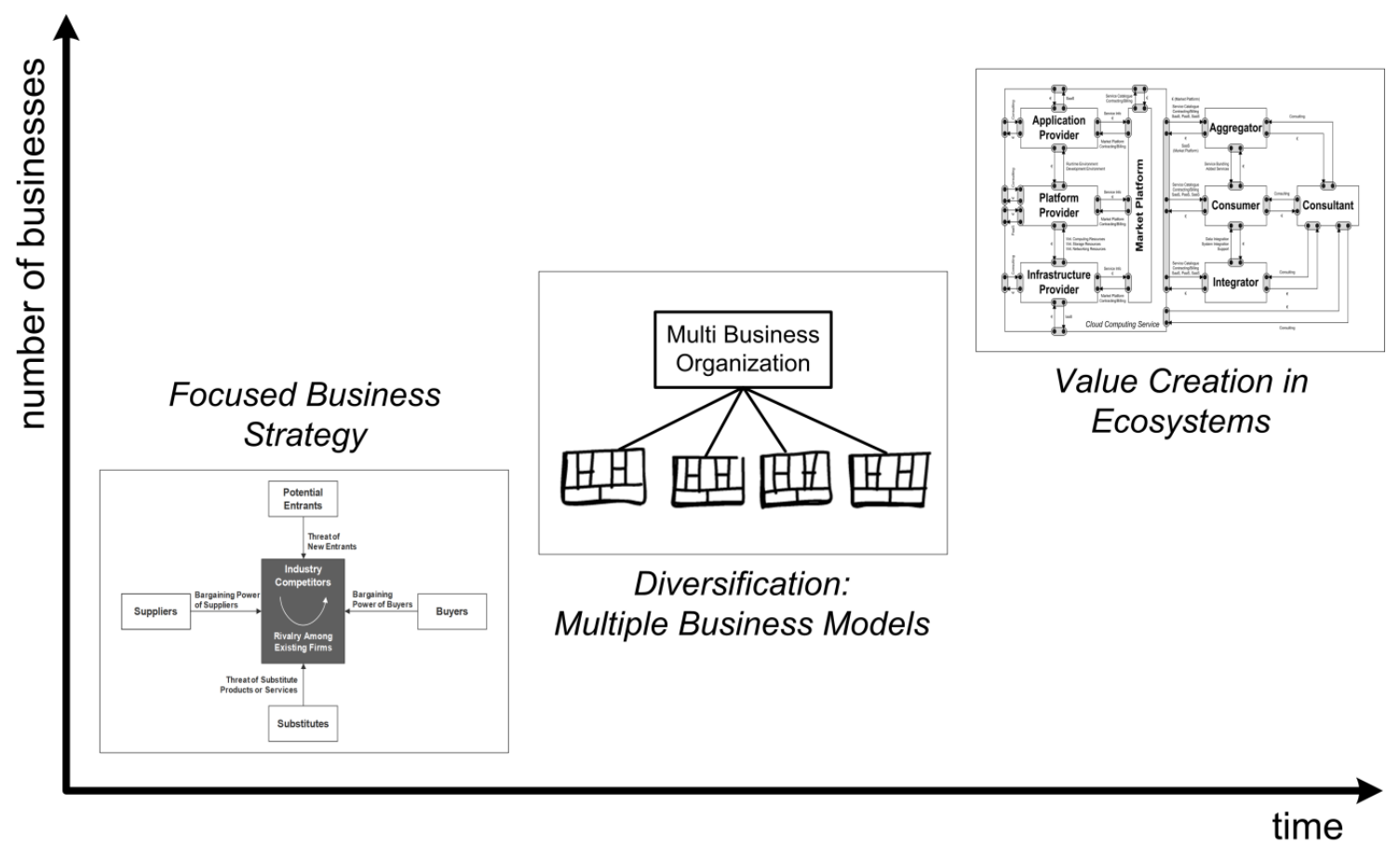

Figure 3: Evolvement of business model foci over time Source: Own illustration

frameworks have evolved. Gordijn and Akkermans (2001, 2003) have suggested the e3-value methodology to analyze value streams among participants of an ecosystem.

Figure 3 illustrates the evolvement of different frameworks over time according to the number of businesses that are subject to strategic thinking and business model development.

\section{Open Innovation}

In the $20^{\text {th }}$ century, many leading industrial companies generated, developed and commercialized ideas for innovations in self-reliance. Today, companies are increasingly rethinking the process of managing their innovation activities. Overcoming company's boundaries in order to open up to other sources of innovation has become increasingly important. In this context, customers are seen 
as a large resource for innovations (Chesbrough 2007b; Chesbrough and Crowther 2006; Enkel et al. 2005; Kristensson et al. 2002).

Customer and user integration into innovation activities is a mode of value creation (Chesbrough 2007b). Companies gather ideas for innovations from customers and users by integrating them into the early stages of the innovation process. The ideas expressed by customers reflect their needs and wishes and have been described as 'need information' (Enkel et al. 2005; von Hippel 1994). Additionally, customers can also express their suggestions on how to transfer these ideas into marketable products, which have been called 'solution information' (von Hippel 1994).

The underlying idea of integrating customers into the early stages of the innovation process is the following: the integration of stakeholders will open up the company's innovation funnel whereby potential perspectives or ideas for creating innovations come into the innovation process (Zhang et al. 2008). Put differently, the amount of innovation potential that can be poured into the innovation funnel increases because more parties are actively involved. Thus, the company gains more ideas for innovations. Surowiecki (2005) describes this concept as follows: "large groups of people are smarter than an elite few, no matter how brilliant - better at solving problems, fostering innovation, coming to wise decisions, even predicting the future". This principles is referred to as 'collective intelligence' or 'wisdom of crowds' (Libert and Spector 2007; Surowiecki 2005). Figure 4 compares open and closed innovation processes. 

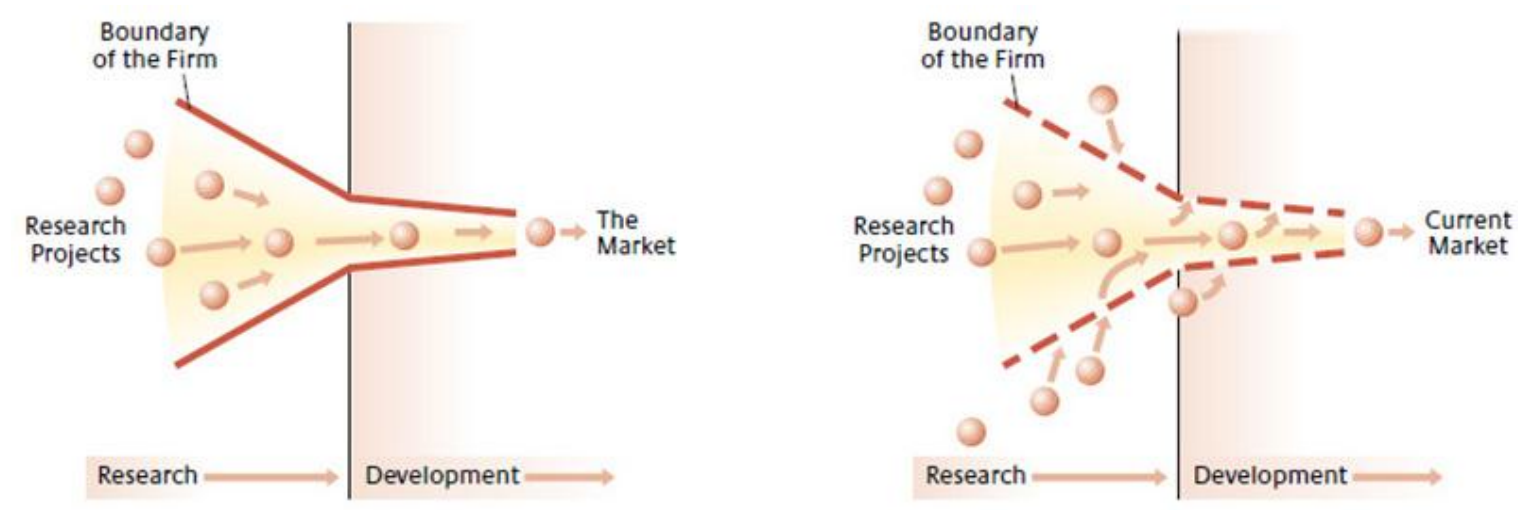

Figure 4: Open vs. closed innovation process, adapted from

Source: Chesbrough (2003)

\section{Freemium Services \& Micro Payments}

The evolution of the Internet technology and e-commerce has provided new possibilities for companies to do business. Also the business models have changed significantly. Traditional business models, exchanging goods and money have been complemented by new forms, where the organization earns its money indirectly. A famous example is Google, which provides search services for free, but earns money with paid third party advertisement.

More recently, a large number of companies have adopted a business model where they give their basic product away for free and charge a premium for specialized functions and services. This business model, referred to the 'freemium' business model is described by Wilson (2006) in his blog. Examples would be social networks like LinkedIn or Xing, which allow everybody to join and network, but request money for extended search and mailing. Other examples are games were one only has to pay for additional characters, gadgets or levels, as well as Skype, which only charges for network-external phone calls. The freemium business model basically draws on two aspects. First, the organization tries to rapidly increase its user base to realize benefits from a critical mass and potentially create a user lock-in. Second, they bet on a large number of 
small payments, often referred to as 'micro payments'. Customers tend to reflect less about small expenses, rather than large ones. This also might lead to unpremeditated buying behavior.

\section{Research Agenda}

\section{Business Model Innovation, Renewal E Co-Creation}

Business models can be a source of competitive advantage, enabling superior value creation (Morris et al. 2005) or even change the economics of an industry (Magretta 2002). Highly innovative business models may change the way of doing things in an industry. Apple's iTunes music store is a good example of that. Initially starting as a complementary service to promote their iPod music players, they have today established a common way to sell and distribute music. Many others, such as Amazon or MusicLoad have adopted this business model. Driven by the success in the music business, Apple has incrementally extended this business model to include movies, e-books, smartphone applications and now even computer software. The recently launched Mac App Store again has the potential to change the way software will be sold, distributed and updated.

As Chesbrough (2007a) highlighted, technological innovations are important, but might not be sufficient to secure an organizations survival. He claims that technology per se has no inherent value and that competition exclusively based on technological innovation is becoming more difficult due to shortening product life cycles and increasing R\&D costs. A better business model, however, has the chance to outperform a better technology. In the same vein, different authors have found business model innovation as an important aspect for firm performance and valuation (e.g. Giesen et al. 2007; Linder and Cantrell 2000; Weill et al. 2011; Zott and Amit 2008). 
Future research should thus address the role of innovation to develop sustainable business models. To provide a foundation for future research, different types and building blocks of business model innovation need to be identified. Especially for practitioners, frameworks and tools to support business model innovation would be useful. Hence, existing tools, such as the business model canvas (Osterwalder and Pigneur 2010) need to be evaluated regarding their suitability and potentially be extended.

Furthermore, the concept of open innovation could take a central role. Through open innovation and different collaborative tools, the co-creation of business models would be imaginable. This enables different stakeholders, such as businesses, consumers, citizens and the government to contribute to value creation for society.

\section{Questions to address could include:}

- What are building blocks of business model innovation?

- How can business model innovations disrupt industries?

- How can business model innovations be supported (frameworks, tools, etc.)?

- How can different stakeholders co-create business models?

- How can business model co-creation leverage societal value creation?

- How can societal value be measured?

- How to avoid value loss for certain stakeholders?

\section{Business Model Mapping E Diffusion}

In the year 2000, a significant number of business failures, leading to the burst of the dot-com bubble raised the question of what distinguished successful from unsuccessful business models. Also today, incorporations are opposed by a large 
number of bankruptcies. As described earlier, various authors propose that innovative business models tend to be more successful (e.g. Giesen et al. 2007; Linder and Cantrell 2000; Weill et al. 2011; Zott and Amit 2008). However, this is still very broad and unspecific. While it definitely has some explanatory power, especially for incumbent firms, it cannot explain the many business failures in the dot-com era. An innovative business model could be attested to many of the failed business. Perhaps they were too innovative and thus risky or insufficiently implemented.

Drawing on this discussion, business model innovation should only be one building block of future business model research, as there must be other factors as well, which distinguish successful from unsuccessful business models. To systematically approach the question of what characteristics or elements distinguish successful from unsuccessful business models, an approach should be developed to collect and map various business models along their characteristics and time. This of course requires suitable business model typologies and modeling languages. However, here it would be possible to draw on previous business model research.

In a longitudinal study, observing business models over time, evolutionand diffusion-patterns could be identified. This would answer the question of what business models or what components of business models are adopted in an industry, as well as how. Furthermore, common characteristics of winning and losing business models could be identified.

This could also lead to a discussion on how the success of a business model could be evaluated. Today, firm performance in terms of profits or stock market valuation is commonly used. However, more comprehensive success measures should be developed to regard the objectives of different stakeholders, such as society and government. This research aspect has its foundation in the 
assumption that financially successful business models could have negative effects for society (see section 0 ).

\section{Questions to address could include:}

- How can business models be mapped along time and characteristics?

- Are current business model typologies and modeling tools sufficient for mapping?

- What are common and distinguishing characteristics of business models?

- What business models are adopted in an industry?

- How are business models adopted in the industry?

- What are common characteristics of winning business models?

- What are common characteristics of losing business models?

- What would be a comprehensive, multi-stakeholder success metric?

\section{Business Model Governance}

Current developments to integrate external ideas through mechanisms of open innovation or the increasing cooperation of organizations in value networks raise important questions regarding the ownership of business models as well as their leadership across organizations.

An important issue in open innovation will be the intellectual property of those ideas. This is further complicated if ideas are developed conjointly. Similarly business models that are developed or renewed by leveraging external ideas are subject to intellectual property issues. Therefore business model research should also address legal issues and try to answer the question of who is the owner of a business model. This also includes issues regarding adoption of other companies' business models. Similar issues arise in ecosystems, when several organizations cooperate in a value network and develop a joint business model. 
Managerial and especially leadership issues in the context of value networks are rather unexplored. Håkansson and Ford (Hakansson and Ford 2002) have highlighted the complexity of managing relationships within business networks. Agranoff (2007) has for example studied the management within networks of public organizations. Möller et al. (2005) have suggested a four level management framework for business networks. This framework highlights challenges arising at different levels: network visioning and orchestration, net management, portfolio management, and relationship management. However, these approaches appear not to be sufficient for the management and leadership within business models that are based on inter-organizational value networks. Future research should therefore investigate, whether traditional management and leadership approaches are sufficient for an efficient management of an ecosystem. This includes the question of whom to appoint for a leadership position among peer-organizations.

\section{Questions to address could include:}

- What legal regulations are setting the boundaries for business models?

- Are there intellectual property rights on business models?

- Are existing leadership approaches sufficient to manage value networks?

- What would be approaches to efficiently manage value networks? 


\section{Societal Implications of Specific Business Models}

Business models might not only have implications for the organization or the ecosystem that uses it, but also for other external stakeholders and eventually the society. Google might be an example of that. Basically, the company's business model is built around data brokerage. Google collects all kinds of data, from websites to mails or geographical information and provides this information for its users, together with paid advertisement. Many users perceive Google's service as useful and agree with their data privacy policy. However Google's activities also have negative effects for people that do not agree with their data privacy policy and thus don't use their services. But actually they can hardly avoid that information about them is collected by Google. Their e-mails being mailed to a Google-user are for example also indexed, as well as their homes mapped on Google Earth or Street View. The latter could be used by burglars trying to identify lucrative and easy victims.

Also freemium services, as described above, are a current trend that has societal implications. Today a large number of services and applications is available free of charge for the majority of people. This could have significant effects for the society. On the one hand people with lower income are now given the access to more and more information, as well as the possibility to use applications that were too expensive for them. On the other hand it might also influence the attitude of people, e.g. their willingness to pay or the demand for more and more governmental services.

Future business model research should thus also take the societal aspect into account. As business models, or more precisely the activities imposed by them, can have an effect on different stakeholders and eventually on our society. Researchers should therefore study the positive and negative implications of new business models. 
Questions to address could include:

- How do business models influence different stakeholders in good and in bad?

- What are societal implications of selected business models?

- What would be possibilities to protect uninvolved stakeholders from negative business model effects?

\section{A Future Insight Process for Knowledge Creation}

As the discussion above highlighted, business model research is a very topical and multidisciplinary domain. Also the different research streams suggested above mutually influence each other or can draw on findings provided by another stream. Therefore a regular exchange of research findings and new ideas would be valuable to advance business model research and transfer findings into society and industry. Therefore a revolving conference is suggested to enhance theoretical and practical exchange. This would also draw additional attention to the institute and establish as an active member of the research community. 


\section{References}

Agranoff, R. 2007. Managing within Networks: Adding Value to Public Organizations. Washington, D.C.: Georgetown University Press.

Alt, R., and Zimmerman, H.D. 2001. "Introduction to Special Section on Business Models," Electronic Markets (11:1), pp. 3-9.

Amit, R., and Zott, C. 2001. "Value Creation in E-Business," Strategic Management Journal (22:6-7), pp. 493-520.

Applegate, L.M. 2001. "Emerging E-Business Models: Lessons from the Field."

ARD. 2011. "Geschichte Der Wirtschaftskrisen: Von Der Tulpenkrise Zur Aktuellen Schuldenkrise." wissen.ARD.de Retrieved 2011-09-29, from http://web.ard.de/galerie/content/nothumbs/default/890/html/1177_8391.ht $\mathrm{ml}$

Baatz, E.B. 1996. "Will Your Business Model Float?," WebMaster Magazin (cited in Scheer et al. 2003)).

Baines, T.S., Lightfoot, H.W., Evans, S., Neely, A., Greenough, R., Peppard, J., Roy, R., Shehab, E., Braganza, A., Tiwari, A., Alcock, J.R., Angus, J.P., Bastl, M., Cousens, A., Irving, P., Johnson, M.W., Kingston, J., Lockett, H., Martinez, V., Michele, P., Tranfield, D., Walton, I.M., and Wilson, H. 2007. "State-ofthe-Art in Product-Service Systems," Proceedings of the Institution of Mechanical Engineers, Part B: Journal of Engineering Manufacture (221:10), pp. 1543-1552.

Bartelt, A., and Lamersdorf, W. 2000. "Geschäftsmodelle Des Electronic Commerce: Modellbildung Und Klassifikation," Tagungsband der Verbundtagung Wirtschaftsinformatik 2000, F. Bodendorf and M. Grauer (eds.): Shaker, pp. 17-29.

Bieger, T., Bickhoff, N., and Knyphausen-Aufseß, D.z. 2002a. "Einleitung," in Zukünftige Geschäftsmodelle: Konzepte Und Anwendungen in Der Netzökonomie, T. Bieger, N. Bickhoff, R. Caspers, D.z. Knyphausen-Aufseß and K. Reding (eds.). Berlin: Springer.

Bieger, T., Rüegg-Sturm, J., and Rohr, T.v. 2002b. "Strukturen Und Ansätze Einer Gestaltung Von Beziehungskonfigurationen - Das Konzept Geschäftsmodell," in Zukünftige Geschäftsmodelle: Konzepte Und 
Anwendungen in Der Netzökonomie, T. Bieger, N. Bickhoff, R. Caspers, D.z. Knyphausen-Aufseß and K. Reding (eds.). Berlin: Springer.

Björkdahl, J. 2009. "Technology Cross Fertilization and the Business Model: The Case of Integrating Icts in Mechanical Engineering Products," Research Policy (38), pp. 1468-1477.

Böhm, M., Leimeister, S., Riedl, C., and Krcmar, H. 2009. "Cloud Computing: Outsourcing 2.0 Oder Ein Neues Geschäftsmodell Zur Bereitstellung Von It-Ressourcen?," Information Management \& Consulting (forthcomeing), p. n/a.

Bonaccorsi, A., Giannangeli, S., and Rossi, C. 2006. "Tntry Strategies under Competing Standards: Hybrid Business Models in the Open Source Industry," Management Science (52:7), pp. 1085-1098.

Bouwman, H. 2008. Mobile Service Innovation and Business Models. Berlin: Springer.

Brousseau, E., and Penard, T. 2006. "The Economics of Digital Business Models: A Framework for Analyzing the Conomics of Platforms," Review of Network Economics (6:2), pp. 81-110.

Carroll, J.R., and Trebnick, C. 1997. "Business Case Modeling for New Ventures," Annual Review of Communications), pp. 149-157.

Casadesus-Masanell, R., and Ricart, J.E. 2010. "From Strategy to Business Models and onto Tactics," Long Range Planning (43:2-3), pp. 195-215.

Chesbrough, H. 2003. Open Innovation. The New Imperative for Creating and Profiting from Technology. Boston, MA: Harvard Business School Press.

Chesbrough, H. 2007a. "Business Model Innovation: It's Not Just About Technology Anymore," Strategy and Leadership (35), pp. 12-17.

Chesbrough, H. 2007b. Open Business Models, ([Nachdr.] ed.). Boston, Mass.:

Chesbrough, H. 2010. "Business Model Innovation: Opportunities and Barriers," Long Range Planning (43), pp. 354-363.

Chesbrough, H., and Crowther, A.K. 2006. "Beyond High Tech: Early Adopters of Open Innovation in Other Industries," R\&D Management (36:3), pp. 229236.

Chesbrough, H., and Rosenbloom, R.S. 2002. "The Role of the Business Model in Capturing Value from Innovation: Evidence from Xerox Corporation's Technology Spin-Off Companies," Industrial and Corporate Change (11:3), pp. 529-555. 
Clemons, E.K. 2009. "Business Model for Monetizing Internet Applications and Web Sites: Experience, Theory and Predictions," Journal of Management Information Systems (2), pp. 15-41.

Doz, Y.L., and Kosonen, M. 2010. "Embedding Strategic Agility," Long Range Planning (43:370-382).

Drucker, P.F. 1954. The Practice of Management. New York: Harper and Row Publishers.

Enkel, E., Perez-Freije, J., and Gassmann, O. 2005. "Minimizing Market Risks through Customer Integration in New Product Development: Learning from Bad Practice," Creativity and Innovation Management (14:4), pp. 425437.

Eriksson, H.-E., and Penker, M. 2000. Business Modeling with Uml: Business Patterns at Work. New York, NY: Wiley \& Sons.

Giesen, E., Berman, S.J., Bell, R., and Blitz, A. 2007. "Three Ways to Sucessfully Innovate Your Business Model," Strategy and Leadership (35:6), pp. 27-33.

Gluck, F. 1980. "Strategic Choice and Resource Allocation," McKinsey Quarterly (1:Winter), pp. 22-34.

Gordijn, J., and Akkermans, H. 2001. "E3-Value: Design and Evaluation of EBusiness Models," IEEE Intelligent Systems (16:4), pp. 11-17.

Gordijn, J.a., and Akkermans, H. 2003. "Value-Based Requirements Engineering: Exploring Innovative E-Commerce Ideas," Requirements Engineering (8:2), pp. 114-134.

Hakansson, H., and Ford, D. 2002. "How Should Companies Interact in Business Networks?," Journal of Business Research (55:2), pp. 133-139.

Hayashi, A.M. 2009. "Do You Have a Plan "B"?," MIT Sloan Management Review (51), pp. 10-11.

Heinrich, B., and Leist, S. 2000. "Bankenarchitekturen Im Informationszeitalter Zur Rolle Des Geschäftsmodells," in Business Engineering - Auf Dem Weg Zum Unternehmen Des Informationszeitalters, H. Österle and R. Winter (eds.). Berlin: Springer.

Institut der Deutschen Wirtschaft Köln. 2011. Deutschland in Zahlen 2011. Köln: Institut der Deutschen Wirtschaft Köln.

Johnson, M.W., Christensen, C.M., and Kagermann, H. 2008. "Reinventing Your Business Model," Harvard business review (86:12), pp. 50-59. 
Johnson, M.W., and Suskewicz, J. 2009. "How to Jump-Start the Clean Tech Economy," Harvard business review (87:11), pp. 52-60.

Kagermann, H., and Österle, H. 2007. Geschäftsmodelle 2010. Wie Ceos Unternehmen Transformieren. Frankfurt am Main: Frankfurter Allgemeine Buch.

Klueber, R. 2000. "Business Model Design and Implementation for Services," Proceedings of the Americas Conference on Information Systems (AMCIS 2000), H.M. Chung (ed.), Long Beach, CA: Association for Information Systems.

Kristensson, P., Magnusson, P.R., and Matthing, J. 2002. "Users as a Hidden Resource for Creativity: Findings from an Experimental Study in User Involvement,", Creativity and Innovation Management (11:1), pp. 55-61.

Leimeister, J.M., and Krcmar, H. 2004. "Revisiting the Virtual Community Business Model," Proceedings of the Tenth Americas Conference on Information Systems, New York.

Libert, B., and Spector, J. 2007. We Are Smarter Than Me: How to Unleash the Power of Crowds in Your Business. Prentice Hall.

Linder, J., and Cantrell, S. 2000. "Changing Business Models: Surveying the Landscape," Accenture Institute for Strategic Change.

Lindström, C.-G. 1999. "Lessons Learned from Applying Business Modelling: Exploring Opportunities and Avoiding Pitfalls," in Perspectives on Business Modelling, A.G. Nilsson, C. Tolis and C. Nellborn (eds.). Berlin: Springer, p. 152.

Magretta, J. 2002. "Why Business Models Matter," Harvard business review (80:5), pp. 86-93.

Mahadevan, B. 2000. "Business Models for Internet-Based E-Commerce: An Anatomy," California Management Review (42:4), pp. 55-69.

Martinez, P. 2000. "Models Made "E": What Business Are You In?," IBM Global Services, Somers, NY.

McGrath, R.G. 2010. "Business Models: A Discovery Driven Approach," Long Range Planning (43), pp. 247-261.

Mercer Management Consulting. 2002. "Herausforderung Profitables Wachstum. Pressemitteilung Vom 02.12.2002 (Cited in Scheer Et Al. 2003),").

Möller, K., Rajala, A., and Svahn, S. 2005. "Strategic Business Nets--Their Type and Management," Journal of Business Research (58:9), pp. 1274-1284. 
Morris, M., Schindehutte, M., and Allen, J. 2005. "The Entrepreneur's Business Model: Toward a Unified Perspective," Journal of Business Research (58:6), pp. 726-735.

Nilsson, A.G., Tolis, C., and Nellborn, C. 1999. "Perspectives on Business Modelling: Understanding and Changing Organisations," in Perspectives on Business Modelling, A.G. Nilsson, C. Tolis and C. Nellborn (eds.). Berlin: Springer.

Österle, H. 1996. "Business Engineering: Transitiion to the Networked Enterprise," Electronic Markets:6), p. 16.

Osterwalder, A. 2004. "The Business Model Ontology - a Proposition in a Design Science Approach." Lausanne: University of Lausanne.

Osterwalder, A., and Pigneur, Y. 2002. "An E-Business Model Ontology for Modeling E-Business," Proceedings of 15th Bled Electronic Commerce Conference, Bled, Slovenia.

Osterwalder, A., and Pigneur, Y. 2010. Business Model Generation: A Handbook for Visionaries, Game Changers, and Challengers. Hoboken, NJ: John Wiley \& Sons.

Osterwalder, A., and Pigneur, Y. 2011. Business Model Generation: A Handbook for Visionaries, Game Changers, and Challengers. Hoboken, NJ: John Wiley \& Sons.

Osterwalder, A., Pigneur, Y., and Tucci, C.L. 2005. "Clarifying Business Models: Origins, Present, and Future of the Concept," Communications of the association for Information Systems (16:1), pp. 1-25.

Pauwels, K., and Weiss, A. 2008. "Moving from Free to Fee: How Online Firms Market to Change Their Business Model Successfully," Journal of Marketing (72), pp. 14-31.

Porter, M.E. 1980. Competitive Strategy: Techniques for Analyzing Industries and Competitors. New York: Free Press.

Porter, M.E. 2001. "Strategy and the Internet," Harvard Business Review (79:3), p. 73.

Rentmeister, J., and Klein, S. 2001. "Geschäftsmodelle in Der New Economy," WISU - das Wirtschaftsstudium:3), p. 356.

Richardson, J. 2008. "The Business Model: An Integrative Framework for Strategy Execution," Strategic Change (17:5/6), pp. 133-144. 
Robert, M., and Racine, B. 2001. E-Strategy - Pure \& Simple: Connecting Your Internet Strategy to Your Business Strategy. New York, NY: McGraw-Hill.

Santos, J., Spector, B., and Van Der Heyden, L. 2009. "Toward a Theory of Business Model Innovation within Incumbent Firms," INSEAD, Fontainebleau, France.

Scheer, C., Deelmann, T., and Loos, P. 2003. "Geschäftsmodelle Und Internetbasierte Geschäftsmodelle - Begriffsbestimmung Und Teilnehmermodell," Johannes Gutenberg Universität Mainz: Chair for Information Systems \& Management.

Schögel, K. "Bezugsrahmen Der Geschäftsmodellierung," in Roadm@P to EBusiness - Wie Unternehmen Das Internet Erfolgreich Nutzen, M. Schögel, T. Tomczak and C. Belz (eds.). St. Gallen: Thexis, pp. 374-399.

Seppänen, M., Helander, N., and Mäkinen, S. 2007. "Business Models in Open Source Value Creation," in Handbook of Research on Open Source Software: Technological, Economic and Social Perspectives, K. St.Amant and B. Still (eds.). Hershey, PA: Idea Group Publishing, pp. 578-589.

Servatius, H.-G. 2002. "Geschäftskonzept-Optimierung in Der NetzwerkÖkonomie," Controlling (14:8/9), pp. 437-455.

Shafer, S.M., Smith, H.J., and Linder, J.C. 2005. "The Power of Business Models," Business Horizons:48), pp. 199-207.

Smith, W.K., Binns, A., and Tushman, M.L. 2010. "Complex Business Models: Managing Strategic Paradoxes," Long Range Planning (43), pp. 448-461.

Stähler, P. 2002. Geschäftsmodelle in Der Digitalen Ökonomie. Lohmar, Köln: Josef Eul.

Surowiecki, J. 2005. The Wisdom of Crowds. Random House Inc.

Tapscott, D., Lowy, A., and Ticoll, D. 2000. Digital Capital: Harnessing the Power of Business Webs. Cambridge, MA: Harvard Business School Press.

Teece, D.J. 2010. "Business Models, Business Strategy and Innovation," Long Range Planning (43:2-3), pp. 172-194.

Timmers, P. 1998. "Business Models for Electronic Markets," Electronic Markets (8:2), pp. 3-8.

Voelpel, S., Leibold, M., Tekie, E., and Krogh, G. 2005. "Escaping the Red Queen Effect in Competitive Strategy: Sense-Testing Business Models," European Management Journal:1), pp. 37-49. 
von Hippel, E. 1994. "''Sticky Information" And the Locus of Problem Solving: Implications for Innovation," Management Science (40:4), pp. 429-439.

Weill, P., Malone, T.W., and Apel, T.G. 2011. "The Business Models Investors Prefer," MIT Sloan Management Review (52:4), pp. 17-19.

Weill, P., and Vitale, M.R. 2001. Place to Space: Migrating to E-Business Models. Boston, MA: Harvard Business School Press.

Weiner, N., Renner, T., and Kett, H. 2010. Geschäftsmodelle Im Internet Der Dienste: Aktueller Stand in Forschung Und Praxis. Stuttgart: Fraunhofer Verlag.

Welge, M.K., and Al-Laham, A. 2008. Strategisches Management: Grundlagen, Prozess, Implementierung. Wiesbaden: Gabler.

Willars, H. 1999. "Business Modeller's Checklist: "Dos" and "Don'ts" in Hands-on Practice," in Perspectives on Business Modelling, A.G. Nilsson, C. Tolis and C. Nellborn (eds.). Berlin: Springer.

Wilson, F. 2006. "My Favorite Business Model." Retrieved 2011-09-16, from http://avc.blogs.com/a_vc/2006/03/my_favorite_bus.html

Zhang, X., Miao, C., Li, Y., and Zhang, H. 2008. "Beyond Product Customization:

Towards a Conceptual Framework for Collaborative Customer Innovation,"

in: 12th International Conference on Computer Supported Cooperative Work in Design (CSCWD).

Zimmermann, H.-D. 2000. "Understanding the Digital Economy: Challenges for

New Business Models," Proceedings of the Americas Conference on Information Systems (AMCIS 2000), H.M. Chung (ed.), Long Beach, CA: Association for Information Systems, pp. 729-732.

Zott, C., and Amit, R. 2008. "The Fit between Product Market Strategy and Business Model: Implications for Firm Performance," Strategic Management Journal (29:1), pp. 1-26.

Zott, C., Amit, R., and Massa, L. 2010. "The Business Model: Theoretical Roots, Recent Developments, and Future Research," IESE Business School University of Navarra, Barcelona. 